\title{
KNOWLEDGE AND FORMS IN PLATO'S EDUCATIONAL PHILOSOPHY
}

\author{
Mason Marshall \\ Religion and Philosophy Division \\ Pepperdine University
}

\begin{abstract}
Aвstract. In this essay, Mason Marshall argues that Plato's views on Forms play a central role in his educational philosophy. In response to what certain commentators have recently written, Marshall contends that this interpretation not only is accurate but also is advantageous because of how it can help philosophy of education. He also addresses the view, proposed by one philosopher of education, that Plato believes that the most valuable sort of knowledge cannot be fully expressed in words and that the objects of this knowledge are something other than transcendent Forms. Preferable to that view, Marshall argues, is the idea that Plato wants knowledge of Forms which is nonrepresentational.
\end{abstract}

Key Words. Plato; knowledge; Forms; aims of education; interpretation; ineffability

To many people, Plato can seem antiquated. One reason for this is his political views and his treatment of rhetoric and art; most off-putting for many of his readers is the theory of Forms - understandably, since it can look untenable and strange. For those of us who want to defend Plato, it is tempting to downplay the theory of Forms or to try to divorce him from it, as certain commentators in philosophy of education have done lately. ${ }^{1}$ I will argue here, however, that it is a mistake to do so because Plato's views about Forms play a central role in his educational thought, and this is for the better rather than the worse. ${ }^{2}$ For reasons I will add, especially problematic is one recent interpretation according to which Plato

1. Much as Mark Jonas argues that Plato is neither the intellectualist nor the elitist he has been taken to be, he holds that Plato posits only immanent forms, meaning, presumably, Aristotelian natural kinds; following Iris Murdoch, Jonas regards Plato's talk of transcendent Forms as strictly a metaphor for "the ethical reality of existence" (Mark E. Jonas, "Three Misunderstandings of Plato's Theory of Moral Education," Educational Theory 66, no. 3 [2016]: 317). Mintz stops short of ascribing a theory of Forms to Plato and, in a book-length treatment of him, mentions Forms only four times (see Avi I. Mintz, Plato: Images, Aims, and Practices of Education [Cham, Switzerland: Springer, 2018], 29n5, 34, 50). On one of those occasions, he mentions them in the course of discussing the view that Plato has no doctrines. Contrast this with Avi I. Mintz, "'Chalepa Ta Kala,' 'Fine Things are Difficult': Socrates' Insights into the Psychology of Teaching and Learning," Studies in Philosophy and Education 29, no. 3 (2010): 295-296.

2. They play a central role at least in one phase of his educational thought and, thus, in the whole. For certain scholars known as developmentalists, there were distinct phases of Plato's thinking, including one in which he accepted the theory of Forms and a later one in which he abandoned it. My touchstone herein are four dialogues that many developmentalists have thought he authored during the first of those two periods - the Phaedo, Phaedrus, Republic, and Symposium - though I bracket the question of whether developmentalism is true. I do assume that there is a unified set of views that emerges in those four dialogues such that we can legitimately interpret them in light of one another. To my mind, scholars such as Lloyd Gerson, Thomas Brickhouse, and Nicholas Smith have replied adequately to the claim that we must read each of Plato's dialogues separately from the others. See Lloyd P. Gerson, From Plato to Platonism (Ithaca, NY: Cornell University Press, 2013), 36ff; and Thomas C. Brickhouse and Nicholas D. Smith, Socratic Moral Psychology (New York: Cambridge University Press, 2010), 31-34. 
simultaneously rejects Forms and holds that the most valuable sort of knowledge is ineffable.

My argument in this essay proceeds as follows: In the first section, I claim that Plato thinks knowledge of the Forms is the central aim of education. In the second section, I argue that this view about his posture toward the Forms is not only accurate, but is also advantageous, because of how it can help philosophy of education. In the third section, I address the interpretation mentioned previously, according to which Plato believes in ineffable knowledge but not in Forms. Throughout this essay, I presume that, whatever else they might be, the Forms are abstract, immaterial, changeless, flawless, and transcendent. They are flawless insofar as they never suffer the compresence of opposites, as it is called; for example, they are never good in some respects yet bad in others (see, for example, Republic 523b-524d, Symposium 211a-b). ${ }^{3}$ And they are transcendent inasmuch as they would continue to be (or, speaking loosely, to exist) even if they were exemplified by nothing other than themselves.

\section{Plato on the Central Aim of Education}

When I say that knowledge of the Forms is, for Plato, the central aim of education, I mean that, as Plato saw it, equipping people with this knowledge is the task to focus on if you want them to achieve what is most important namely, virtue and happiness. ${ }^{4}$ In the course of explaining why he thought this, I will indicate that he had serious reasons for his claims, reasons that perhaps are not decisive but are substantial enough to be worth considering, as long as he was correct in believing that there are Forms. In the next section, I will point to a reason Plato could offer for saying that there are. My discussion in this section, however, touches on a range of scholarly issues that are significant but that tend to be distracting, so to address them I will rely heavily on notes.

The first point to make is that, for Plato, knowing and contemplating the Forms are part of being happy, where happiness is conceived not as contentment, but as flourishing. ${ }^{5}$ Plato indicates as much about our relation to the Forms (see, for

3. Herein all references to Plato's works are to the texts edited by John Burnet and S. R. Slings for the Oxford Classical Texts series, and all translations are based on the ones in John M. Cooper, ed., Plato: Complete Works (Indianapolis, IN: Hackett, 1997).

4. This has to be qualified, though only slightly. You equip people with this knowledge insofar as you lead some of them to it, and then they are guided by it and guide the others, such that the others, too, are guided by it. In the Republic and maybe also in dialogues such as the Phaedrus (see, for example, чохทें пробі́коoøav, "a proper soul," at 276e6), the thought is that certain people are unsuited to know the Forms.

5. Jonas's main reason for denying that Plato believes in Forms is that they are described in his dialogues only in the middle of myths and metaphors (see Jonas, "Three Misunderstandings of Plato's Theory of Moral Education"). But in the debate among scholars about what status Plato's myths have, one defensible and longstanding view is that he believes they convey philosophical truths as much as his

MASON MARSHALL is Associate Professor of Philosophy in the Religion and Philosophy Division, Seaver College, Pepperdine University; email mason.marshall@pepperdine.edu. His primary areas of scholarship are ancient philosophy and classical American philosophy. 
example, Republic 611d-612a, Symposium 211d), and it is easy enough to see why. For him, they act as causes (see especially Phaedo 96-106); for example, the Form of the Good causes the goodness of all the other Forms and everything else that is good: they are good by virtue of participating in the Good (see especially Republic $505 a 3-4) .{ }^{6}$ In order to have this causal power, the Form of the Good must itself be good, and one can only imagine that the goodness of it and the other Forms is supreme, as a number of passages in the dialogues suggest (see, for example, Phaedo 74d5-8, 75a11-b3, Republic 508e-509b). ${ }^{7}$ If this is correct, it is no wonder that knowing and contemplating the Good are the ultimate bliss, as Plato implies (see, for example, Republic 519c5-6, 580d-588a) - not just gratifying but profoundly fulfilling.

As Plato sees it, there is also another connection between happiness and knowing the Forms. It is that knowing them is both necessary and sufficient for being virtuous, while being virtuous is necessary for being happy. (Plato may even believe that virtue is sufficient for happiness. ${ }^{8}$ I I will take these claims in order.

First, Plato thinks that knowledge of the Forms is necessary for virtue in the sense that no one is virtuous (or fully virtuous, at least) unless they know the Forms. One reason he holds this view is that he believes that someone who knows the Form of the Good, for example, knows the nature of goodness, and thus sees what makes something good, such that they can reliably discern between those actions that are good and those that are not and, in turn, be in position to act well.

arguments do. For surveys of the debate, see, for example, Daniel S. Werner, Myth and Philosophy in Plato's "Phaedrus" (New York: Cambridge University Press, 2012), 9-13; and Catalin Partenie, "Introduction," in Plato's Myths, ed. Catalin Partenie (Cambridge: Cambridge University Press, 2009), 5-21. To show that Plato thinks the Forms would be humanly unreachable, Jonas quotes Phaedo 66d7-e6 ("Three Misunderstandings of Plato's Theory of Moral Education," 321). But that passage is not clear-cut. By contrasting it with other parts of the Phaedo, such as $72 \mathrm{e} 3-78 \mathrm{~b} 3$ and $78 \mathrm{~b} 4-84 \mathrm{~b} 4$, we can say that Socrates is just hyperbolic in it. Regarding this point, see Gerson, From Plato to Platonism, 163-165, and F. C. White, "Socrates, Philosophers and Death: Two Contrasting Arguments in Plato's Phaedo," Classical Quarterly 56, no. 2 (2006): 449n24, both of which contain other references. There are similar points to make about passages such as Phaedrus $278 \mathrm{~d} 3-6$. Incidentally, Jonas does think that one purpose of the dialogues is to convey views that Plato endorses, views which are more or less on the surface of the text (see "Three Misunderstandings of Plato's Theory of Moral Education," 316n25). In this section, accordingly, I assume that the dialogues have that purpose.

6. I leave this vague on purpose. Interpreters have disagreed about which of the following Plato has in mind: formal causation, efficient causation, final causation, or all three. See D. T. J. Bailey, "Platonic Causes Revisited," Journal of the History of Philosophy 52, no. 1 (2014): 15-32, for discussion and references.

7. Richard Kraut also is right to cite Republic 476b, 480a, 484b, 490a-b, 500c, and 501d, wherein the Forms are the proper objects of love. Richard Kraut, "The Defense of Justice in Plato's Republic," in The Cambridge Companion to Plato, ed. Richard Kraut (New York: Cambridge University Press, 1992), 334 n19.

8. If so, he thinks it is sufficient in the sense that, if you are virtuous, you will be happy. Julia Annas and Martha Nussbaum are among those who hold that he thinks this. Julia Annas, Platonic Ethics, Old and New (Ithaca, NY: Cornell University Press, 1999); and Martha Craven Nussbaum, "Aristotle on Emotions and Rational Persuasion," in Essays on Aristotle's "Rhetoric," ed. Amélie Rorty (Berkeley: University of California Press, 1996), 313. 
Someone who does not know the nature of goodness is far more likely to make an error in judgment and, in turn, to act poorly. ${ }^{9}$ Moreover, if they, by chance, have the correct views about goodness, they might end up losing them, since someone might convince them that their views are false. If you lack knowledge of the Good, then you must ultimately reason from hypotheses, in Plato's language (Republic $510 \mathrm{bff}$ ), meaning hunches that are resilient but unsubstantiated, such that, at least in principle, someone can talk you out of them. Though you might have reasons for many of your views (and reasons for those reasons, and so on), one or more of your reasons is inevitably only postulated, and thus all of them can slip from your grasp. The situation is different if you know the Good. The Forms are what is, or, more colloquially, they are what is real; their analog is the sun in Plato's famous allegory of the cave. ${ }^{10}$ And the Form of the Good is that on account of which they are and on account of which they are knowable (Republic 508e-509b). Accordingly, knowledge of the Good is as stable as knowledge can be: since, for example, its object is the very source of knowability, it is not something you can lose, and rightly so, either because it is undoubtable, because it is self-confirming, or because it consists in part of reasons that cannot be refuted. Thus, virtuous people know the Form of the Good, since by knowing it they will always have their power to recognize how to act virtuously. ${ }^{11}$

These are reasons Plato can offer, and there is a lot he can say in defense of them. If, for example, there is such a thing as the Form of the Good, it is easy to imagine that it is, indeed, what makes the world knowable. Not just according to Plato, but in fact, "goodness is fundamentally about intelligibility," as one scholar puts it; "it is the evaluative term in which we make sense of our actions, the actions of others, and the world." 12 For example, no one's behavior can make sense to us unless we suppose that they are pursuing something that, in their mind, is worth achieving. And insofar as they think it is worth achieving, it is something of value to them, something which in that respect they consider good, supposing goodness need not be moral purity, for example, but can be just what is beneficial, useful, or the like.

9. Compare with, especially, Republic 505e3-5, 506c-d; contrast with Meno 97b9-10, though also see c6-8. Annas questions how useful the Form of the Good is supposed to be (Platonic Ethics, Old and New, chap. 5). There are replies in, among other places, Chris Bobonich, "What's the Good of Knowing the Forms?," in Philosophy and Political Power in Antiquity, ed. Cinzia Arruzza and Dmitri Nikulin (Leiden, MA: Brill, 2016), 67-93; and Andrea Wilson Nightingale, Spectacles of Truth in Classical Greek Philosophy: Theoria in Its Cultural Context (New York: Cambridge University Press, 2004), 127-131.

10. On the most obvious reading of Republic 475e-480a, what Socrates and his interlocutors call "what is" is being; what they call "what both is and is not" is between being and not-being; and what they call "what is not" is not-being. On this interpretation and two of its defensible competitors, see David C. Lee, "Interpreting Plato's Republic: Knowledge and Belief," Philosophy Compass 5, no. 10 (2010): 854-864, which contains references.

11. For other reasons to think that knowledge is, for Plato, necessary for virtue, see Christopher Bobonich, Plato's Utopia Recast: His Later Ethics and Politics (New York: Oxford University Press, 2002), 43 with 489n45; and Terence Irwin, Plato's Ethics (Oxford: Oxford University Press, 1995), 231-235.

12. Melissa Lane, Eco-Republic: What the Ancients Can Teach Us about Ethics, Virtue, and Sustainable Living (Princeton, NJ: Princeton University Press, 2012), 134. The next two sentences paraphrase Lane. 
Let me move, then, to the next point. Plato thinks that knowledge of the Forms is sufficient for virtue in the sense that you will be virtuous as long as you know the Forms. In his view, if you know the Form of the Good, for example, you cannot help but live in accordance with it, such that who you are and what you do are shaped by it. There are at least two reasons to think that he accepts this. One is that his Socrates nearly says it at times (see, for example, Republic 500d1-2,501d7-9). More important is a passage in the Republic where Socrates describes the good as "what every soul pursues and for the sake of which it does everything it does" (505e1-2). ${ }^{13}$ The idea there, as elsewhere in Plato, is that the good is what we are really after, and the only reason we ever pursue anything else is that we mistake it for what is good. In other words, it is strictly because we are ignorant of the good that we fail to live it out (505e2-5). ${ }^{14}$

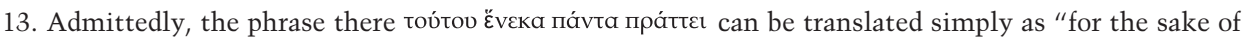
which it takes all pains," to paraphrase A. W. Price, Virtue and Reason in Plato and Aristotle (New York: Oxford University Press, 2011), 277. But I think the immediate context, especially 505b5-6 together with e2-5, favors my translation. Translations of this sort have often been thought to clash with Republic 4, but certain scholars have argued compellingly that they do not; for a summary and references, see Rachel Singpurwalla, "Reasoning with the Irrational: Moral Psychology in the Protagoras," Ancient Philosophy 26, no. 2 (2006): 256n16. Like Gabriela Carone, I believe that, in the Republic, Plato denies the possibility of any akratic action, including not only that which is contrary to one's knowledge of what is best, but also that which is contrary to one's belief about it (Gabriela Roxana Carone, "Akrasia in the Republic: Does Plato Change his Mind?," Oxford Studies in Ancient Philosophy 20 [2001]: 107-148). One can argue, though, as Thomas Gardner does, that Plato denies the possibility of the former, but accepts the possibility of the latter, even while holding that all desires are good-dependent (Thomas Gardner, "Socrates and Plato on the Possibility of Akrasia," Southern Journal of Philosophy 40, no. 2 [2002]: 191-210). For a recent statement of the view that Plato accepts the possibility of both sorts of akratic action in the Republic, see Christopher Bobonich, "Agency in Plato's Republic," in Oxford Handbooks Online (2017), https://www.oxfordhandbooks.com/ view/10.1093/oxfordhb/9780199935314.001.0001/oxfordhb-9780199935314-e-7, which contains other references.

14. Perhaps the true object of our desire is not just goodness but the Form of the Good: the Symposium $(209 \mathrm{e}-212 \mathrm{a})$ says that the Form of Beauty is what we want, and Beauty therein is analogous to the Good in the Republic. More vexing is the part of the Republic (519c-521b) where Socrates says that young philosophers in training, once they have come to know the Forms, will have to be compelled to return to the cave to rule in the city, as justice requires them to (for example, 519e-521b). That passage has troubled scholars, and it poses a problem for me if it means that the young philosophers, even after knowing the Forms, will not be motivated enough on their own to do what is just. I think it does not mean this, though. In brief, the compulsion to rule is, in my view, internal to the young philosophers, and it is overwhelmingly strong because of their knowledge of the Forms. In taking this view, I follow commentators such as Irwin (Plato's Ethics, chap. 18) and Kraut ("The Defense of Justice in Plato's Republic," 327-329), but I should stress that acting on the compulsion, as I see it, will not lead the young philosophers to sacrifice their happiness. (It is problematic to say that it will, as certain other scholars have emphasized.) Rather, the happiness they will enjoy after returning to the cave is the greatest happiness available to them. My reason is that, since justice requires that they rule, they could stay outside the cave only if they let their souls be governed by one of its baser parts instead of by reason, and then they would suffer from being unjust, the way Republic 8 and 9 warn that all unjust souls do. In saying this, I imply that, ultimately, the urge to stay outside the cave would come only from one of the baser parts of the soul; and one can object that the Republic suggests otherwise at 519c4-6 and $520 \mathrm{e} 1-521 \mathrm{~b} 11$. But I think there is a way to accommodate both of these passages, as well as the ones which indicate that the compulsion comes from the city's founders rather than from within the young philosophers themselves. On all these passages, see Christopher Buckels, "Compulsion to Rule in 
An implication is that, if we know what the good is, we will aim at it without fail. ${ }^{15}$

These views, too, have a lot in their favor. Take, for example, the idea that all our actions aim at the good. It is hard to reject that point fundamentally while still allowing that our evaluative judgments are connected to our motivations and actions. And to deny a connection of that sort is to face considerable challenges, at least if one wants to say that human beings act freely rather than simply under compulsion. ${ }^{16}$

Consider, finally, the idea that virtue is necessary for happiness. Plato may have a number of reasons for taking this stance. The most obvious, perhaps, emerges in the discussion of unjust souls in Republic 8 and 9. One thought there is that, at root, virtue involves recognizing something of value beyond your own desires and tailoring them to it. Left alone, they will eventually overwhelm you, since they tend to grow only stronger and harder to satisfy. When they reach full strength, they lead to profound frustration, both for you and the people around you. These are empirical claims, of course, and the Republic asserts them more than it defends them. But we can see their force even just by observing our own mental lives and the tendencies each of us displays. Everyone has at least had the experience of indulging a desire only to see it then grow stronger.

To be sure, Plato recognizes limits to what knowing the Forms can do for us: he might concede to Aristotle that it will not fully equip you to practice medicine or be a carpenter, for example. ${ }^{17}$ If Plato believes those activities are teachable, perhaps he thinks that the know-how they require is an additional aim of education, separate from knowledge of the Forms. But if so, he takes the former aim to be secondary to the latter. Socrates claims at one point in the Republic that, unless one has knowledge of the Form of the Good, all other knowledge, even the

Plato's Republic," Apeiron 46, no. 1 (2013): 63-83; and Eric Brown, "Justice and Compulsion for Plato's Philosopher-Rulers," Ancient Philosophy 20, no. 1 (2000): $5 \mathrm{ff}$.

15. Republic $518 \mathrm{~d} 9-11$ does indicate that habituation and practice are necessary (and perhaps that they are sufficient) for the virtues of courage, justice, and temperance, as Jonas emphasizes (see "Three Misunderstandings of Plato's Theory of Moral Education," 306). But the habituation and practice required for knowing the Forms instill those virtues as a byproduct of preparing us to gain knowledge or to follow the person who has it. And it is only a byproduct. Plato may even view the moral virtues as less significant than the intellectual virtues; see, for example, Dominic Scott, Levels of Argument: A Comparative Study of Plato's "Republic" and Aristotle's "Nicomachean Ethics" (New York: Oxford University Press, 2015), 81n25; and David Sedley, "The Ideal of Godlikeness," in Plato, vol. 2: Ethics, Politics, Religion, and the Soul, ed. Gail Fine (Oxford: Oxford University Press, 1999), 322-323. This is one consequence of Republic 518d9-e1, and it must inform our interpretation of passages such as 395c3-d3 and 522a3-9, both of which Jonas quotes in Mark E. Jonas, "Plato's Anti-Kohlbergian Program for Moral Education," Journal of Philosophy of Education 50, no. 2 (2016): 207.

16. See, for example, Sergio Tenenbaum, "The Judgment of a Weak Will," Philosophy and Phenomenological Research 59, no. 4 (1999): 885ff; and Sarah Buss, "Weakness of Will," Pacific Philosophical Quarterly 78, no. 1 (1997): 26-31.

17. See Aristotle, Nicomachean Ethics 1097a8-13. 
fullest share of it, is of no benefit (505a). And this claim, like the others, has a lot behind it, such as a point Socrates makes in Plato's Euthydemus (279a-282c), where he says that all kinds of knowledge (in fact, all resources whatsoever) are of no help unless you know how to use them, or which ends to put them toward that are good. In fact, Socrates implies that, if anything, having them without knowing how to use them is worse than not having them at all, since they enable you to do greater harm than you could do without them. There is room to disagree with him on this point, of course, but his view makes sense and even has a certain appeal.

I conclude that Plato thinks knowledge of the Forms is the central aim of education and that he has serious reasons for taking this view, reasons that are worth considering as long as he is right to think that there are Forms. Part of what I will do in the next section is point to a reason that Plato could offer for saying that there are - a reason which is similar to one he names (Republic 477c-480a, Timaeus 51d-e) but which draws in part on contemporary epistemology.

\section{Forms AND Nonrepresentational KNOWLedge}

Just now I argued, in effect, that the Forms are deeply important to Plato. I will add that not only is it accurate to say that they are, but it also is advantageous. Here is one reason this is so.

First, once we say it, there are robust models of knowledge that we can ascribe to Plato. ${ }^{18}$ According to one of them, for example, the objects of all knowledge are Forms, which, in his terminology, are essence (or being: oúoia), ${ }^{19}$ and essence is also what human persons are. The meaning of that claim is involved, and, happily, there is no need to go into it here. The important point is that, on this model, there is identity between Forms and us such that we can achieve oneness with them and, in turn, knowledge of them that is nonrepresentational insofar as it consists of unmediated cognitive access to them.

The impulse is to ask why one would want to ascribe such a view to Plato, since it not only is eccentric but also can seem patently false. Oddly enough, though, there turns out to be considerable force behind it, particularly because of modern epistemology's discovery of the Gettier problem, as it is called, and the extent to which epistemologists struggled to solve it in the decades following its discovery. The significance of the Gettier problem is that it poses a difficulty for the standard analysis on which knowledge is justified true belief. This analysis is standard (or

18. The following model comes from Gerson, in particular, though I greatly simplify his account. Among his relevant works is Lloyd P. Gerson, Knowing Persons: A Study in Plato (Oxford: Oxford University Press, 2003).

19. On the claim in the Republic that the Form of the Good is "beyond" or "above essence"

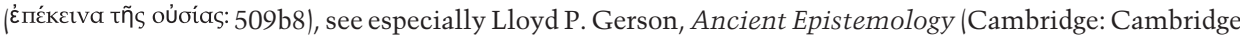
University Press, 2009|, 28. 
was) for the obvious reason: it can seem clear that knowledge involves true belief, and it is natural to think the belief must be justified, since otherwise, perhaps, nothing ensures that it is true. The problem is that we can imagine cases where a belief is justified and nevertheless is true just by chance, such that it apparently does not amount to knowledge.

Suppose, for example, that my friend tells me my car has been stolen, and with justification I believe her. Suppose, further, that she does not believe the car is missing - she is only playing a trick on me - but, as luck would have it, the car in fact has been stolen. In that case, I have a belief that is true and justified, but it is true only by chance, and thus it seems not to be knowledge.

Epistemologists worked for years to repair the standard analysis so that it would accommodate cases like that one; for example, they tried to find something besides justification that could be added to belief in order to guarantee its truth. Arguably, they never quite succeeded, and the reason is that the standard analysis is irreparable and has to be scrapped entirely. As many epistemologists now agree, it does not work to analyze knowledge as true belief, plus some other factors that make it knowledge. ${ }^{20}$ In fact, knowledge cannot be in any part belief. After all, if knowledge involves belief, it involves representing the objects of knowledge, whereupon there is always a chance of misrepresenting them; yet knowledge cannot be false - or, at least, to say that it can, as certain epistemologists have, is just to stipulate a definition of the word or concept "knowledge" instead of describing something that genuinely exists. ${ }^{21}$ Thus, rather than representing the objects of knowledge, a knower must be one with them. And Forms are the only sorts of objects that a knower can be one with and that are illuminating enough to be what there is to be known. ${ }^{22}$ This, at least, is a very plausible line of thought, regardless of whether it is ultimately correct.

Accordingly, a Plato who believes in Forms can challenge those of us who hold views about what the aims of education are. Philosophers of education and others have debated which goods education aims at; some have held, for example, that teachers should aim to instill true belief, whereas others have said that the

20. Timothy Williamson has been especially influential on this point. His relevant works include Timothy Williamson, Knowledge and Its Limits (New York: Oxford University Press, 2000).

21. Here I paraphrase Lloyd P. Gerson, "Platonic Knowledge and the Standard Analysis," International Journal of Philosophical Studies 14, no. 4 (2006): 456-457.

22. Contrast Forms with Aristotelian immanent universals, for example. Arguably, the latter cannot adequately account for the values we find. In Aristotle's world, organisms each strive toward the respective ends that are internal to them, yet what explains how these organisms are all part of an ecology or kosmos (Aristotle, Metaphysics 1075a12-25) such that their ends are not at odds with one another? 
goal should be rationality or certain virtues. ${ }^{23}$ Quite possibly, the debate has been too confined, since if there is nonrepresentational knowledge of the sort just described, there is a good chance that it is the aim of education, or at least one of its aims. The idea of involving Plato in the discussion is less strange than it might seem at first. To welcome him into it, one need not think he will prove to be correct: one can simply suspect that wrestling with him will turn out to be productive, particularly because of how different his sensibilities are from ours. As a number of historiographers have emphasized, thinkers in history are useful for making us reconsider the assumptions that we are prone to take for granted. When we are in agreement with one another on certain points, their truth can seem so obvious that we do not think to defend them, and we overlook objections to them that we would do well to consider, even if the result of considering them is simply that we refine the views we already hold or sharpen our arguments for them. ${ }^{24}$ There is a lot to that notion, and it is borne out in significant ways in philosophy and various other disciplines. For example, many political theorists have found it constructive to address the arguments in Plato's Republic for aristocracy, even though most political theorists today are firmly committed to democracy. ${ }^{25}$

Of course, we might think that, once we have conceived of a view, it makes no difference whether we ascribe it to Plato - for example, that once we have the idea of nonrepresentational knowledge, we might as well detach the idea from him and simply debate it on its own terms. But as historiographers have stressed, it often is helpful to "think with" a historical figure, as they put it: to ascribe a view to that figure and try to reconstruct the reasons he or she has for it, or could have, rather than reasons we imagine independently of the person's writings. ${ }^{26}$ When we do so, we have to work under the constraints the historical figure imposes every claim we attribute to the person has to mesh with all of his or her other

23. For summaries and references, see Kristján Kristjánsson, Flourishing as the Aim of Education: A Neo-Aristotelian View (New York: Routledge, 2019), chap. 2; and Lani Watson, "The Epistemology of Education," Philosophy Compass 11, no. 3 (2016): 151ff.

24. See, for example, Maria Rosa Antognazza, "The Benefit to Philosophy of the Study of Its History," British Journal for the History of Philosophy 23, no. 1 (2015): 161-184; and Yitzhak Melamed, "Charitable Interpretations and the Political Domestication of Spinoza, or, Benedict in the Land of the Secular Imagination," in Philosophy and Its History: Aims and Methods in the Study of Early Modern Philosophy, ed. Mogens Lærke, Justin E. H. Smith, and Eric Schliesser (Oxford: Oxford University Press, 2013), $258-277$.

25. See, for example, David M. Estlund, "Why Not Epistocracy?," in Desire, Identity, and Existence: Essays in Honor of T. M. Penner, ed. Naomi Reshotko (Edmonton, Canada: Academic Printing and Publishing, 2003), 53-69 (revised and reprinted as "Why Not an Epistocracy of the Educated?," in Democratic Authority: A Philosophical Framework [Princeton, NJ: Princeton University Press, 2008], 206-222); and Robert B. Talisse, Democracy after Liberalism: Pragmatism and Deliberative Politics (New York: Routledge, 2005), 99ff.

26. See, for example, Richard Sorabji, "Ideas Leap Barriers: The Value of Historical Studies to Philosophy," in Maieusis: Essays in Ancient Philosophy in Honour of Myles Burnyeat, ed. Dominic Scott (Oxford: Oxford University Press, 2007), 384; and Ryan Nichols, "Why Is the History of Philosophy Worth Our Study?," Metaphilosophy 37, no. 1 (2006): 46-47. 
claims - so, in the process of trying to trace the person's thoughts, we can think of inferences, among other things, that would not have occurred to us otherwise, whereupon we can end up with sturdier arguments against our views and, thus, better means of strengthening them. In engaging Plato, for example, we can find greater resistance to our views about knowledge and, in turn, to our views about the aims of education.

I have offered only an example of why it is advantageous to say that the Forms are important to Plato. There are other examples one could name. But I think this one, even by itself, attests that there is a lot to be gained.

\section{FORMLESS INEFFABILISM}

I shift now to consider an interpretation of Plato that one philosopher of education, Mark Jonas, has recently offered. Like the interpretation I just discussed, it is ineffabilist, as I will put it, meaning that it says that, for Plato, the sort of knowledge most worth having cannot be fully expressed in words. Unlike that other interpretation, though, it denies that the objects of this knowledge are Forms, in his view. ${ }^{27}$ I will call this interpretation Formless ineffabilism and will argue that it is problematic - more specifically, that it is problematic relative to philosophy of education. To start with, I will note an obstacle for ineffabilism in general, one that certain sorts of ineffabilism can manage but that causes trouble for Formless ineffabilism, in particular.

The main evidence in favor of ineffabilism of any kind is in the Seventh Letter, an epistle ascribed to Plato. Many scholars have doubted that he is in fact its author, and here I will leave open the question of whether he is. The following passage in the letter is clearly significant, though, especially if Plato is its author:

There is no writing of mine about this matter [namely, the knowledge of mine that I hold most dear], nor will there ever be; for this knowledge is not something that can be put into words like other sciences, but after long-continued intercourse between teacher and pupil, in joint pursuit of the subject, suddenly, like light flashing forth when a fire is kindled, it is born in the soul and straightaway nourishes itself. $(341 \mathrm{c} 4-\mathrm{d} 2)^{28}$

27. See Mark E. Jonas, "Plato on Dialogue as a Method for Cultivating the Virtues," in The Theory and Practice of Virtue Education, ed. Tom Harrison and David Ian Walker (New York: Routledge, 2018), 87ff in light of note 1 above. Like Jonas, Mintz accepts ineffabilism (see Plato: Images, Aims, and Practices of Education, 29), though he and Jonas may have different ideas about what the objects of Plato's ineffable knowledge are and the extent to which it is expressible. For Jonas, perhaps, it is simply nonpropositional knowledge of how to live well, and one can make statements that capture some features of its content; see Mark E. Jonas, "The Role of Practice and Habituation in Socrates' Theory of Ethical Development," British Journal for the History of Philosophy 26, no. 2 (2018): 987-1005, especially 1003. For Mintz, conceivably, its objects are ineffable propositions, and it is wholly inexpressible in words.

28. The Greek that is translated here as "is not something that can be put into words like other sciences"

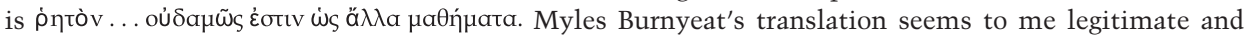
maybe even preferable: "It cannot be conveyed [to someone else] by words in anything like the same way as other studies can" (Myles Burnyeat and Michael Frede, The Seventh Platonic Letter: A Seminar, ed. Dominic Scott [Oxford: Oxford University Press, 2015], 166). I offer a more conventional translation here just to keep from loading the dice. 
This passage suggests not only the limits of writing, but the inadequacy of all words, even spoken ones, ${ }^{29}$ so it can seem to show definitively that ineffabilism is correct.

One problem, however, is that the passage is in tension with certain parts of Plato's dialogues. Consider, for example, the following exchange in the Republic:

Socrates: Do you call dialectical someone who is able to give a logos of the being of each

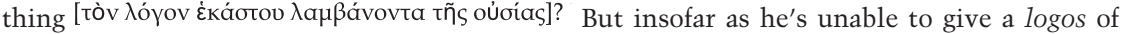
something, either to himself or to another, do you deny that he has any understanding of it?

Glaucon: How could I do anything else?

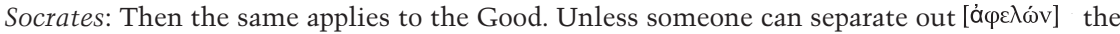

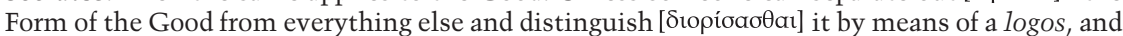

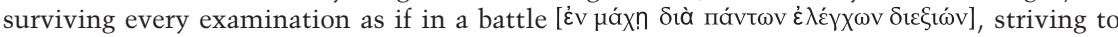
judge things not in accordance with opinion but in accordance with being, he comes through all this with his logos still intact, you'll say that he doesn't know the Good itself or any other good? And if he gets hold of some image of it, you'll say that it's through opinion, not knowledge, for he is dreaming and asleep throughout his present life, and before he wakes up here, he will arrive in Hades and go to sleep forever?

Glaucon: Yes, by god, I'll certainly say all of that. $(534 \mathrm{~b} 3-\mathrm{d} 2)^{30}$

As it is conceived in the Republic, knowledge of the Form of the Good is the be-all and end-all knowledge, and on its face the Republic indicates that we do not have knowledge of that sort unless we can articulate what we know, provide arguments for our claims, and reply satisfactorily to every objection that can be raised. The implication is that the most valuable sort of knowledge is fully articulable; this is implied even by the claim that the knower can give arguments, since a proposition can be the conclusion of an argument only if the proposition can be conveyed in words. So passages such as this one offset the Seventh Letter, and they offset it enough that, if they and it are our only evidence, the texts underdetermine which interpretation is correct, ineffabilism or one of its competitors.

The obvious solution is to look beyond the Seventh Letter and find something else in Plato's writings that favors ineffabilism. However, although there is additional evidence, ${ }^{31}$ it is available only to interpreters who say that Plato believes in

29. Among other reasons, the term that I have translated "can be put into words" (’́ntóv: 341c5) means simply that; it does not mean "expressible in writing." I paraphrase K. M. Sayre, "Review of Plato and the Foundations of Metaphysics: A Work on the Theory of the Principles and Unwritten Doctrines of Plato with a Collection of the Fundamental Documents by Hans Joachim Krämer," Ancient Philosophy 13,

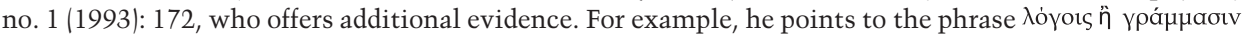
("speaking or writing") at 343d4-5.

30. See also Apology 22b3-c8; Gorgias 465a2-5, 500e4-501a3; Meno 98a; Phaedo 76b8-c3; Phaedrus 278c5-6; Republic 531e3-5; Theaetetus 187b2-210b3; and Timaeus 51e3-4.

31. Take, for example, Socrates's claim in the Republic that each Form is "one" (ש̌v; see 476a3, 479a4, 507b5-6). Arguably, Socrates means both that each Form is incomposite and that it is isolated from other Forms (since it is wholly and purely self-predicated), so he implies that Forms are indefinable, since nothing can be definable without having either connections among its parts or relations to other things. If so, knowledge is ineffable (or, at least, ultimate knowledge is) as long as Forms are its objects, as they of course are if Plato believes in Forms. 
Forms; for interpreters who say otherwise, there is not much to find. Of the various letters attributed to Plato, the Seventh Letter is the only one that is a real candidate for being authentic, so the extra evidence would have to come from Plato's dialogues. And the dialogues give us little that is helpful once we suppose that they are Formless: though many of them accommodate ineffabilism, they accommodate anti-ineffabilism, too, such that one has to read them through the lens of the Seventh Letter in order to accept ineffabilism.

Plato's Lysis is a case in point, I think, and I imagine that Jonas would agree, despite what he has written about it. Here is the key passage in it, one that opens with a statement from Socrates that is part of a long discussion about the nature of love:

\footnotetext{
"And if one person desires another ... or loves him passionately, he would not desire him or love him passionately or as a friend unless he somehow belonged to his beloved either in his soul or in some characteristic, habit, or aspect of his soul."

"Certainly," said Menexenus, but Lysis said nothing.

"All right," [Socrates] said, "what belongs to us by nature has shown itself to us as something we must love."

"It looks like it," [Menexenus] said.

"Then the genuine and not the pretended lover must be befriended by his boy."

Lysis and Menexenus barely somehow nodded assent, but Hippothales beamed every color in the rainbow in his delight. $(221 \mathrm{e} 7-222 \mathrm{~b} 2)$
}

Jonas claims that this passage "provides ... an image" of how one achieves the ineffable knowledge mentioned in the Seventh Letter. ${ }^{32}$ This idea, besides being intriguing, is certainly plausible, and it is plausible precisely for the reason Jonas proposes, which is that Lysis is silent here because he has an "epiphany," meaning "an awakening or a spontaneous realization that ... is not entailed by the logical argumentation Socrates employs." 33 But even if Lysis does have an epiphany, it is not clear from the text that he comes to understand anything substantial, such as the nature of love, much less that his discovery is inexpressible to any extent. ${ }^{34}$ (Perhaps all he realizes, for example, is that he should stop ignoring Hippothales, an older boy who passionately pursues him as a lover.) So, although the Lysis allows Jonas's interpretation, the Lysis itself provides no reason to prefer it. The text thus is flexible in a way that is characteristic of Plato's dialogues and that is exacerbated once we suppose they are Formless. Especially once we decide that they are, the challenge in interpreting them is to find passages that can determine the correct reading instead of being determined by it.

32. Jonas, "Plato on Dialogue as a Method for Cultivating the Virtues," 90.

33. Mark E. Jonas, "Education for Epiphany: The Case of Plato's Lysis," Educational Theory 65, no. 1 (2015): 42n12.

34. In fact, neither is it clear that he has an epiphany. Maybe the only reason he falls silent is that he anticipates and dislikes Socrates's conclusion. See especially Terry Penner and Christopher Rowe, Plato's “Lysis" (New York: Cambridge University Press, 2005), 168. 
Of course, like the passage in the Lysis, the Republic passage quoted previously is in the dialogues, and it, too, is flexible: there are ways to redescribe it so that it does not mean that knowledge can be conveyed fully in words. ${ }^{35}$ It might seem, then, that the solution is to bend the Republic passage so that it fits with the Seventh Letter. The problem is that, if Plato does not believe in Forms (or might not), we can instead bend the Seventh Letter so that it fits with the passage in the Republic, and there is no decisive reason to bend the one rather than the other. After all, the dialogues, at the least, strongly suggest that Plato believes in Forms they encourage us to assume that he does - so if he does not, he is highly strategic as an author: he writes less to convey his beliefs to his readers than to have some other effect on them, whatever it is. This matters because, if he is as cagey as this implies, we cannot take the dialogues at face value, in which case neither can we take the Seventh Letter at face value. In antiquity, a letter of its kind was "a public presentation and interpretation of a position, not a personal outpouring from one individual to another," as Julia Annas has put it. ${ }^{36}$ Accordingly, as she and others have said, Plato might be no more forthcoming in the Seventh Letter than in the dialogues, supposing he is its author. ${ }^{37}$

Moreover, it is easy enough to imagine that he would be no more forthcoming in the Seventh Letter, particularly since it contains the remark I quoted above. No matter how Plato conceives of knowledge, he plainly wants us to inquire, in part by weighing arguments and counterarguments; this, at least, we can gather from the dialogues. ${ }^{38}$ Yet inquiry is difficult and time-consuming, and there is for many people a deep temptation to avoid it. Further, the way most people avoid it is by telling themselves that they already have knowledge such that they need not seek it. (At least, Plato apparently thinks that this is the common tactic, since it is the favorite one among Socrates's interlocutors in the dialogues.) The way to hold them accountable is to do what Socrates does with his interlocutors and what Plato often does with his readers: confront them with questions that they struggle to answer, and suggest to them that they don't have knowledge until they are able to answer them - in other words, until they can defend their claims. If you commend to them the idea that there is knowledge which is ineffable, you imply that there is

35. See especially Francisco J. Gonzalez, Dialectic and Dialogue: Plato's Practice of Philosophical Inquiry (Evanston, IL: Northwestern University Press, 1998), 239-240; and Kenneth M. Sayre, Plato's Literary Garden: How to Read a Platonic Dialogue (Notre Dame, IN: University of Notre Dame Press, 1995), 194-195. Roughly, Gonzalez and Sayre say that the point of passages like this one is just that people who have ineffable knowledge do not fall prey to the limitations of language and, in turn, do injustice to what they know; in fact, they talk in a way that conduces to ineffable knowledge among their listeners.

36. Annas, Platonic Ethics, Old and New, 75.

37. See, for example, Ruby Blondell, The Play of Character in Plato's Dialogues (Cambridge: Cambridge University Press, 2002), 38; and Charles L. Griswold Jr., "Commentary on Sayre," Proceedings of the Boston Area Colloquium in Ancient Philosophy 9, no. 1 (1993): 205.

38. It is generally agreed that, even if Plato thinks knowledge is ineffable, he believes that we need to inquire this way in order to better our chances of reaching knowledge. See, for example, Sayre, Plato's Literary Garden, 90-91. 
knowledge which is indefensible, and thereby you give them an out: you invite them to fancy that they have knowledge already, just as they hoped, and that they thus are off the hook. So - and here is the point - there is reason to think that believing knowledge is ineffable would not be sufficient motivation for Plato to say that it is, especially if he is so cagey as an author.

Why, then, would he make the remark in the Seventh Letter? Perhaps in order to tease readers into looking beyond his dialogues. By dangling the suggestion that the dialogues are inadequate, he would keep readers from assuming that because they had read the dialogues, they already had answers or knew Plato's philosophical views such that they need not inquire or enter his Academy. There is a danger that they would be complacent after reading the dialogues, just as there is a danger that they would be complacent beforehand or in the course of reading them, and Plato might simply think the former danger is greater than the latter. Of course, I am only speculating; if he is the author of the Seventh Letter, maybe he does make the pivotal remark in order to disclose what he believes. But there is a chance, at least, that he does not, enough of a chance that the evidence from the Seventh Letter does not outweigh the evidence from the Republic and other Platonic dialogues.

The upshot is that, once we reject the view that Plato believes in Forms, we reach an impasse: we are unable to say that ineffabilism is more likely than its competitors to be true - true in the sense that it accurately describes Plato's writings, his intentions behind them, or the like. As a result, if we are to prefer Formless ineffabilism, we have to do so for what philosophers call prudential reasons, that is, reasons to think not that Formless ineffabilism is more accurate than the alternatives, but that it is more useful, meaning more conducive to our ends. The distinction among philosophers is between prudential reasons and epistemic reasons. An epistemic reason to believe something (for example, a claim about Plato) is reason to think it is true, whereas a prudential reason to perform some action (for example, to adopt an interpretation) is reason to think that performing this action will further our ends. When epistemic reasons cannot decide an issue, we must resort to prudential reasons if we are to favor any views over others.

All of this is significant since the prudential reasons to favor Formless ineffabilism turn out to be relatively weak. The problem is that there are interpretations more useful to philosophy of education than Formless ineffabilism is. One, for example, is the interpretation described in the previous section, an interpretation that says, in part, that Plato believes in Forms. That interpretation gives Plato a vigorous metaphysics and epistemology, whereupon he can pose resistance to our views about the aims of education and help us refine our thoughts about them. It is hard to see how Formless ineffabilism would be able to do anything comparable.

\section{CONCLUSION}

In this essay, I have argued that Plato's views about Forms play a central role in his educational philosophy. I claimed that this reading not only is accurate, but also is advantageous because of what it can do for philosophy of education. In the same vein, I contended that Formless ineffabilism is problematic. Unless Plato believes in Forms, I argued, ineffabilism is no more likely than its competitors to 
be true. So, if we are to accept Formless ineffabilism, we have to do so for prudential reasons rather than epistemic reasons. Yet the prudential reasons to favor Formless ineffabilism are relatively weak, since there are other interpretations that are more useful than it is. For example, there is the interpretation I described in section two of this essay, according to which Plato believes in nonrepresentational knowledge of Forms, such that he can stir productive debate. All told, I have cast Plato less as an ally than as a provocateur, someone to look to more for a challenge than for inspiration. In this respect, my essay is unusual compared to most recent discussions of him among philosophers of education. But if I am right, a provocative Plato is the sort who can help us the most. 